\title{
SOSIAL SKILL TRAINING PADA KLIEN ISOLASI SOSIAL
}

\author{
Diah Sukaesti ${ }^{1}$ \\ RSJ Dr Soeharto Heerdjan Jakarta \\ diahsukaesti@yahoo.com
}

\begin{abstract}
ABSTRAK
Isolasi sosial merupakan kondisi kesendirian yang dialami individu dan dipersepsikan disebabkan oleh orang lain. Ketidakmampuan mengungkapkan perasaan yang dirasakan oleh klien dapat membuat klien marah.Tujuan penulisan ini menjelaskan manajemen asuhan keperawatan spesialis jiwa pada klien dengan isolasi sosial . Intervensi diberikan pada 30 klien dengan isolasi sosial dengan menggunakan terapi Social Skil training. Hasil didapatkan penurunan tanda dan gejala secara kognitif afektif, fisiologis, perilaku, sosial dan peningkatan kemampuan klien dan keluarga. Rekomendasi penelitian ini adalah klien dengan isolasi sosial dilakukan terapiSocial skill training,
\end{abstract}

Kata kunci: Isolasi sosial,Social skill training,

\section{SOCIAL SKILL TRAINING IN SOCIAL INSULATION CLIENTS}

\begin{abstract}
Social isolation is the condition of being alone as experienced by individual and perceived as caused by others. Inability to express client's feeling can stimuli anger. The purpose of this scientific paper was to explain the mental health-psychiatric nursing care management to clients with social isolation Nursing intervention was conducted to 30 social isolated clients were social skill training, The effect of therapies showed the decreased of sign and symptom at all aspects of cognitive, affective, physiological, behavior, social and improvement of client and family ability. It's recommended that social skill training applied to client with social isolation,
\end{abstract}

Keywords: Social Isolation, Social skill training

\section{PENDAHULUAN}

Isolasi sosial merupakan kondisi kesendirian yang di alami oleh individu dan dipersepsikan disebabkan orang lain dan sebagai kondisi yang negatif dan mengancam (Townsend, 2010). Kondisi isolasi sosial seseorang merupakan ketidakmampuan klien dalam mengungkapkan perasaan klien yang dapat menimbulkan klien mengungkapkan perasaan klien dengan kekerasan.Perilaku kekerasan merupakan respon destruktif individu terhadap stresor (Stuart, 2013). Klien dengan isolasi sosial tidak mampunyai kemampuan untuk bersosialisasi dan sulit untuk mengungkapkan keinginan dan tidak mampu berkomunikasi dengan baik sehingga klien tidak mampu mengungkapkan marah dengan cara yang baik. Tindakan keperawatan yang dilakukan pada klien dengan isolasi sosial dilakukan tindakan generalis. Terapi Aktivitas Kelompok, terapi spesialis yang diberikan adalah dengan memberikan terapi Social Skill Training.

\section{METODE}

Desain Penelitian ini menggunakan "Quasi Eksperimental Pre-post test, responden dalam penelitian ini adalah 30 klien, penelitian ini dilakukan dengan rancangan pre- post test yang dilakukan untuk mengukur tanda dan gejala klien dengan isolasi sosial dan mengukur kemampuan klien sebelum dilakukan asuhan keperawatan dan kemampuan klien setelah dilakukan asuhan keperawatan, serta kemampuan keluarga sebelum dilakukan asuhan keperawatan dan kemampuan keluarga setelah dilakukan asuhan keperawatan pada keluarga. Variabel tersebut diukur dengan menggunakan instrument ceklist dengan jawaban ya dan tidak untuk mengukur tanda dan gejala isolasi sosial dan checklist dengan jawaban mampu dan tidak mampu untuk kemampuan klien dan keluarga. Analisa data disajikan dalam persentase.

\section{HASIL}

Klien dengan isolasi sosial rata-rata berusia dewasa $87 \%$, dengan jenis kelamin laki-laki 
$100 \%$, karena berdasarkan pemilihan tempat diruang rawat laki-laki, tingkat pendidikan yang terbanyak adalah SMA $44.9 \%$ dilanjutkan dengan tingkat pendidikan SD yaitu $36.2 \%$. Status pekerjaan adalah tidak bekerja sebesar $75.4 \%$ dan bekerja sebesar $24.6 \%$. Status Pernikahan tidak kawin $68.3 \%$, menikah sebesar $20.2 \%$, dan janda atau duda sebesar $11.5 \%$. Berdasarkan lama sakit adalah sebesar lebih dari 5 tahun sebesar $40.5 \%$.

Faktor predisposisi klien dengan isolasi sosial dan risiko perilaku kekerasan secara biologis yang terbesar adalah sakit sebelumnya sebesar $47.8 \%$, riwayat Napza 39.1\%. Faktor predisposisi secara psikologis yang terbesar adalah keinginan tidak terpenuhi $23.1 \%$, faktor predisposisi secara sosial adalah masalah pekerjaan sebesar 39.1\%, masalah ekonomi $24.6 \%$. Faktor presipitasi klien dengan isolasi sosial dan risiko perilaku kekerasan secara biologis yaitu putus obat sebesar $71 \%$, masalah psikologis adalah masalah ekonomi $34.7 \%$ dan masalah pekerjaan $31.8 \%$, Faktor presipitasi secara sosial yang terbesar adalah masalah pekerjaan $34.7 \%$.
Sumber koping pada klien isolasi sosial dan risiko perilaku kekerasan untuk personal ability belum mampu bersosialisasi dan mengontrol marah sebesar 89,8\%, sosial support yang terbesar adalah caregiver $73.9 \%$, material aset sebagian besar klien dirawat dengan menggunakan BPJS (Badan Penyelengara Jaminanan Kesehatan) 98.5\%, Keyakinan klien terhdap diri klien sebesar $100 \%$ dan keyakinan klien terhadap petugas kesehatan sebesar $100 \%$.

Mekanisme koping yang digunakan pada klien dengan isolasi sosial dengan menarik diri $78.2 \%$, marah $68.1 \%$, diam sebesar $59.3 \%$, menangis sebesar $15.3 \%$. Penurunan tanda dan gejala klien isoalsi sosial sebelum dilakukan tindakan dan sesudah dilakukan tindakan keperawatan Penurunan tanda dan gejala secara aspek kognitif adalah sebeasar $38.7 \%$, penurunan aspek afektif rata-rata sebesar $29,9 \%$, penurunan tanda dan gejala aspek fisiologis adalah sebesar $48.8 \%$, aspek perilaku sebesar $24.4 \%$ dan secara sosial sebesar $31.9 \%$.

Tabel 1.

Distribusi Kemampuan generalis isolasi sosial $(\mathrm{n}=30)$

\begin{tabular}{lccc}
\hline Kemampuan & Pre $(\%)$ & Post $(\%)$ & Selisih \\
\hline Mampu mengidentifikasi penyebab isolasi sosial & 28 & 100 & 72 \\
\hline Menyebutkan keuntungan bersosialisasi & 28 & 100 & 72 \\
\hline Mampu berkenalan & 21 & 86 & 65 \\
\hline Mampu berbicara dengan orang lain & 14 & 86 & 72 \\
\hline Mampu berbicara dengan orang lain lebih dari 2 & 4.3 & 50 & 45.7 \\
\hline Mampu berbicara sosial saat belanja kewarung & 4.3 & 38 & 3.7 \\
\hline
\end{tabular}

Berdasarkan tabel diatas peningkatan kemampuan klien setelah dilakukan terapi generalis sebesar 58.4\%. Kemampuan klien setelah dilakukan tindakan Terapi Aktivitas Kelompok (TAK) pada klien isolasi sosial terjadi penngkatan sebesar $55.4 \%$. Kemampuan klien setelah dilakukan tindakan Social Skill training adalah 53.6\%. Dapat disimpulkan klien dengan isolasi sosial yang dilakukan tindakan keperawatan mengalami peningkatan kemampuan klien dalam bersosialisasi dengan orang lain baik secara individu maupun secara kelompok.

Tabel 2.

Distribusi kemampuan klien isolasi sosial setelah dilakukan tindakan TAK $(\mathrm{n}=30)$

\begin{tabular}{lccc}
\hline Kemampuan & Pre (\%) & Post (\%) & Selisih \\
\hline Kemampuan memperkenalkan diri & 42 & 100 & 68 \\
\hline Kemampuan berkenalan & 42 & 100 & 68 \\
\hline Kemampuan bercakap-cakap & 14 & 84 & 70 \\
\hline Kemampuan bercakap-cakap topik tertentu & 14 & 84 & 70 \\
\hline Kemampuan bercakap-cakap masalah pribadi & 15 & 84 & 70 \\
\hline Kemampuan bekerjasama & 14 & 84 & 70 \\
\hline Evaluasi kemampuan bersosialisasi & 0 & 42 & 42 \\
\hline
\end{tabular}


Tabel 3.

Distribusi kemampuan klien setelah dilakukan tindakan social Skill Trining

\begin{tabular}{lccc}
\hline Kemampuan & Pre $(\%)$ & Post $(\%)$ & Selisih \\
\hline Latihan sosialisasi & 5.7 & 72.4 & 66.7 \\
\hline Latihan menjalin persahabatan & 2.8 & 65.2 & 62.4 \\
\hline Latihan bekerjasama dalam kelompok & 2.8 & 47.8 & 45 \\
\hline Latihan menghadapi masalah yang sulit & 1.4 & 42.0 & 40.6 \\
\hline
\end{tabular}

Tabel 4.

Distribusi kemampuan keluarga setelah psikoedukasi keluarga $(\mathrm{n}=30)$

\begin{tabular}{lccc}
\hline \multicolumn{1}{c}{ Kemampuan } & Pre $(\%)$ & Post $(\%)$ & Selisih \\
\hline Pengalaman keluarga dalam merawat klien & 8 & 100 & 92 \\
\hline Cara merawat klien & 8 & 80 & 72 \\
\hline Managemen stress & 4 & 72 & 68 \\
\hline Management beban & 0 & 60 & 60 \\
\hline
\end{tabular}

\section{PEMBAHASAN}

Hubungan Interpersonal Peplau dimulai dari fase identifikasi dan fase orientasi, pada tahap ini didapatkan karakteristik klien yang dirawat sebagian besar berusia dewasa yaitu usia antara 25- 59 tahun yaitu sebesar $87 \%$. Hasil penelitian ini sesuai dengan penelitaian yang dilakukan (Sukri, Keliat \& Mustikasari, 2014) dimana klien dengan halusinasi dan isolasi sosial $94.1 \%$ berusia antara $25-44$ tahun. Jenis kelamin klien yang dirawat $100 \%$ berjenis kelamin laki-laki.hal ini disebabkan karena ruang yang digunakan merupakan ruang rawat intermediate laki-laki. Kaplan, Sadock, \& Grebb (2010) menyatakan laki-laki lebih mungkin memunculkan gejala negatif dibandingkan dengan wanita, dan wanita tampak memiliki fungsi sosial yang lebih baik di bandingkan dengan laki-laki.

Tingkat pendidikan pada klien yang dirawat dirumah sakit jiwa dr soeharto Heerdjan rata-rata adalah Sekolah Menengah Atas ( SMA) sebesar 44. 9\%. Pendidikan terendah adalah tidak sekolah sebesar 4.3\%, Sekolah Dasar (SD) sebesar 36.2\% Sekolah Menengah Pertama (SMP) sebesar 13.4\%, Perguruan Tinggi sebesar 4.3\%. Stuart (2013) menyatakan aspek intelektual merupakan salah satu penyebab klien gangguan jiwa, karena berhubungan dengan kemampuan menyampaikan ide atau pendapatnya. Klien yang di rawat sebelum perawatan mayoritas tidak bekerja yaitu sebesar $75.4 \%$.Klien yang bekerja adalah $24.6 \%$. Sosial ekonomi yang rendah merupakan faktor sosial yang menyebabkan tingginya angka gangguan jiwa termasuk Skizofrenia (Towsend, 2009).

Lama sakit klien yang terbanyak adalah lebih dari 5 tahun yaitu sebesar $40.5 \%$, satu sampai 5 tahun adalah sebesar $36.2 \%$. Stuart mengungkapkan klien yang mempunyai lama sakit yang lama mempunyai kemampuan kognitif yang kurang baik sehingga klien sulit untuk melakukan pembelajaran. Klien yang dirawat penangung jawab biaya $98 \%$ adalah menggunakan BPJS, hal ini menguntungkan bagi klien dan keluarga dalam mengurangi beban biaya perawatan klien.

Faktor predisposisi yang terbesar adalah riwayat gangguan jiwa sebelumnya, klien yang telah lama mengalami gangguan jiwa cenderung mempunyai perilaku menarik diri dan komunikasi terbatas hal ini merupakan respon maladaptif dari klien. Semakin lama klien yang mengalami kekambuhan klien banyak mendapatkan stressor dari berbagai aspek kehidupan. Stuart (2013) menyatakan jumlah stressor yang dialami seseorang pada kurun waktu tertentu akan semakin memperburuk akibat yang diterima individu tersebut. Riwayat pengguna napza juga memiliki kontribusi yang besar yaitu $39.1 \%$. Riwayat penggunaan napza berakibat pada kerusakan otak yang akan mempengaruhi proses berfikir, menilai dan mempengaruhi kepribadian seseorang, sehingga kerusakan pada otak bisa mengalami perilaku menarik diri dan risiko perilaku kekerasan. Faktor Predisposisi secara psikologis pada klien dengan isolasi sosial yang terbanyak adalah keinginan tidak terpenuhi yaitu berjumlah $23.1 \%$, pengalaman yang tidak menyenangkan adalah $1.4 \%$ dan tipe kepribadian tertutup adalah $4.3 \%$.

Faktor Predisposisi secara psikologis pada klien dengan isolasi sosial yang terbanyak adalah keinginan tidak terpenuhi yaitu berjumlah $23.1 \%$, pengalaman yang tidak menyenangkan adalah $1.4 \%$ dan tipe kepribadian tertutup adalah 4.3\%.Faktor sosial budaya yang mempengaruhi klien dengan gangguan jiwa adalah usia, jenis kelamin, tingkat pendidikan penghasilan, 
pekerjaan latar belakang budaya, nilai sosial dan pengalaman indiidu (Stuart, 2013). Faktor predisposisi secara sosial budaya pada klien dengan isolasi sosial adalah masalah pekerjaan dimana klien sulit untuk mendapatkan pekerjaan sehingga berdampak pada masalah ekonomi yang dialami oleh klien.

Respons afektif pada klien dengan isolasi sosial adalah merasa sedih, afek tumpul, merasa tidak diperdulikan orang lain, malu kesepian, merasa ditolak orang lain dan merasa tertekan atau depresi. Hal ini sesuai dengan Nanda (2012) respons afektif pada klien isolasi sosial adalah merasa bosan, dan lambat dalam menghabiskan waktu, sedih afek tumpul dan kurang motivasi. Klien yang dirawat dengan diagnosa isolasi sosial mengalami penurunan tanda dan gejala secara afektif rat-rata $29.9 \%$. Penurunan tanda gejala secara afektif yang terbesar dalam karya ilmiah ini adalah merasa tertekan/depresi yaitu sebesar $50.7 \%$, hal ini disebabkan pada klien isolasi sosial sebelum dilakukan intervensi merasa tertekan dan depresi namun dengan menggunakan pendekan hubungan interpersonal Peplau dimana sesuai tahapannya di mulai dari fase orentasi, fase identifikasi, fase eksploitasi dan fase resolusi. pendekatan ini berdampak terhadap perasaan klien tertekan atau depresi karena klien dan perawat sudah terjalin hubungan saling percaya sehingga klien menjadi tidak takut dengan hubungan klien dan perawat, sehingga klien mampu mengeksplorasi perasaan klien dengan baik.

Respons fisiologis pada klien dengan isolasi sosial adalah sulit tidur, wajah murung, kurang bergairah dan merasa letih. Pada asuhan keperawatan ini ditemukan penurunan rata-rata sebesar 48.8\%. Penurunan respons secara fisiologis sejalan dengan pernyataan dari Stuart (2013) yang menyatakan bahwa kerusakan hipotalamus pada klien gangguan jiwa akan membuat seseorang kehilangan mood dan motivasi untuk melakukan sesuatu dan kehilangan mood untuk melakukan kegiatan sosialisasi dengan orang lain. Klien yang dirawat diruangan setelah dilakukan tindakan pemberian terapi social skill training terlihat perubahan secara fisiologis dimana sebelum pemberian terapi wajah klien tampak murung dan cenderung tidak mau tersenyum dan wajah tampak tegang. Pemberian social skill training sesi pertama adalah mengajarkan sikap tubuh klien, dimana klien diajarkan tentang sikap tubuh dalam bersosialisasi dan diajarkan terapi perilaku dimana dilakukan pendekatan kepada klien tentang perilaku klien dalam sikap tubuh. Hal ini didukung oleh hasil penelitaian (Syukri, Keliat \& Mustikasari, 2014) dalam Karya Ilmiah Akhir ini didapatkan penurunan tanda dan gejala secara kognitif, afektif, fisiologis, perilaku dan sosial.

Respons perilaku pada klien dengan isolasi sosial adalah banyak melamun, melakukan pekerjaan tidak tuntas, banyak berdiam diri dikamar, dipenuhi oleh pikiran sendiri dan tidak mampu melakukan kegiatan sehari-hari. Pada penelitian ini didapatkan penurunan rata-rata untuk respon perilaku sebesar $24.4 \%$. Respons perilaku pada klien dengan isolasi sosial sesuai dengan (Keliat, 2010) yang menyatakan bahwa klien respons perilaku yang muncul pada klien dengan isolasi sosial adalah menarik diri, menjauh dari orang lain, tidak atau malas melakukan komuikasi, tidak ada kontak mata, malas bergerak dan melakukan aktivitas, berdiam diri dikamar, menolak berhubngan dengan orang lain dan sikap bermusuhan. Pada karya ilmiah ini respons perilaku yang banyak mengalami penurunan penilaian terhadap stessor adalah berdiam diri dikamar dan melakukan pekerjaan tidak tuntas, tindakan yang dilakukan untuk mengurangi tanda dan gejala ini adalah penulis berusaha untuk memotivasi klien berbicara dengan klien lain supaya klien mempunyai ketrampilan berkomunikasi, dan melibatkan klien dalam kegiatan kelompok, klien dimotivasi untuk menyelesaikan pekerjaan klien sampai selesai.

Membuat kontrak awal kepada klien yang bertujuan membangun kepercayaan klien terhadap perawat.perawat sebagai orang asing harus menempatkan klien dengan penuh perasaan dan mau meneima klien apa adanya, fase ini merupakan dasar untuk dapat melakukan tindakan pada tahap selanjutnya. Seorang perawat harus menggunakan hubungan terapeutik dalam melakukan tindakan kepada klien sehingga klien mempunyai kepercayaan terhadap perawat.Fase orientasi berakhir setelah terbina hubungan saling percaya antara klien dengan perawat yang dlanjutkan dengan fase identifikasi.

Fase identifikasi merupakan fase dimana perawat melakukan pengkajian terhadap klien dengan melakukan eksplorasi perasaan klien. Pengkajian yang dilakukan oleh perawat menggunakan format pengkajian berdasarkan dari Stuart yaitu terdiri dari faktor Predisposisi/ faktor pendukung, faktor presipitasi /faktor pencetus yaitu suatu stimulus yang dipersepsikan oleh individu sebagai suatu kesempatan, ancaman, tuntutan terhadap penilaian stressor. Fase identifikasi ini perawat menggali semua yang di rasakan oleh klien dan 
yang diharapkan oleh klien, hal ini sesuai dengan (Parker \& Smith, 2010) yang menyatakan bahwa pada fase orientasi ini klien mengekspresikan semua perasaan yang ingin diatasi dan perawat membantu klien untuk memperbaiki sesuai dengan apa yang dirasakan oleh klien. pada fase identifikasi ini perawat menentukan diagnosa keperawatan, menentukan tujuan dan kriteian hasil serta menetukan rencana tindakan yanga akan dilakukan dan evaluasi (Peplau, 1992 dalam Parker \& Smith, 2010) Penulis dalam hal ini menetapkan diagnoasa pada klien dengan masalah isolasi sosial dan masalah risiko perilaku kekerasan, menetapkan tujuan dan rencana tindakan yang akan dilakukan dan merencanakan evaluasi yang dilakukan, setelah semua di tetapkan penulis masuk ke tahap kerja/fase eksploitasi.

Fase kerja atau fase eksploitasi merupakan fase dimana perwat melakukan manajemen asuhan pada klien dengan isolasi sosial dan risiko perilaku kekerasan yang dialami oleh klien, penulis mencoba mengatasi dengan pemberian terapi generalis isolasi sosial. . Pemberian terapi ini penulis lakukan dengan bantuan perawat ruangan dan mahasiswa keperawatan yang sedang praktek dengan membagi kasus kelolaan pada saat sedang dilakukan preconference. Sebelum pemberian terapi generalis perawat melakukan pengkajian dan melakukan pre test kepada pasien dengan menanyakan beberapa tanda gejala isolasi sosial, serta kemampuan klien dalam bersosialisasi Pemberian terapi generalis diberikan bersamaan dengan pemberian terapi aktivitas kelompok dan terapi spesialis. Terapy spesialis yang diberikan adalahsocial skill training, Tujuan pemberian terapi ini adalah supaya klien menpunyai kemampuan berkomunikasi yang baik, dan klien mampu merubah peilaku klien yang masih kurang baik dimana hasil akhirnya adalah klien mampu asertif dalam mengatasi semua stessor yang dihadapi oleh klien. Fase eksploitasi merupakan fase dimana klien ketergantungan, kemandirian dan saling ketergantungan yang bertujuan untuk agar klien mampu mengurangi kecemasan dan pada akhirnya klien mampu memecahkan masalahnya sendiri (Fitzpatrik,2005 dalam Parker \& Smith, 2010).

Kemampuan klien setelah dilakukan tindakan social skill training meningkat sebesar 53.4\%, kemampuan klien yang meningkat adalah kemampuan klien dalam berkenalan, sikap tubuh dan menjalin persahabatan, hal ini sejalan dengan penelitian yang dilakukan Libermen dan dan
Martin (2005) yang menyatakan bahwa Sosial skill training membuat klien dengan Skizofrena dapat lebih optimal secara fisik, emosi, sosial dan vocasional, kekeluargaan dan dapat memecahkan masalahnya sendiri meningkat, kemampuan intelektual dalam mensuport diri meningkat. Kemampuan klien setelah dilakukan tindakan keperawatan social skill training meningkat. Tindakan kepeawatan tidak hanya berdampak terhadap kemampuan klien tetapi juga berdampak terhadap kemampuan keluarga.

Psycoedukasi keluarga adalah terapi yang diberikan kepada keluarga, peningkatan kemampuan keluarga meningkat sebesar 73 $\%$.Hal ini sejalan dengan pernyataan dari Rufono, Kuhn dan Evans (2005) yang menyatakan family psikoeukasi dapat meningkatkan kemampuan keluarga dalam problem solving, kemampuan koping keluarga, kemampuan dlam mengasuh klien dengan gangguan jiwa.Psycoedukasi bermanfaatt untuk klien dengan Skizofrenia, hal ini sesuai dengan penelitian yang dilakukan Kulhara at all (2008) Psikoedukasi yang rutin dilakukan kepada keluarga dapat meningkatkan kemampuan keluarga dalam merawat pasien.Meningkatnya kemampuan keluarga dalam merawat klien berdampak terhadap kemampuan keluarga dalam merawat klien sehingga diharapkan kemampuan klien meningkat.

Fase eksploitasi ini perawat memberikan ketrampilan klien dalam bersosiaisasi dan mengubah pikiran dan perilaku klien menjadi pikiran dan perilaku klien yang baik serta pada akhirnya klien mampu bersikap asertif (Peplau 1912 dalam Parker \& Smith, 2010) menyatakan fase orientasi ini adalah dalam memberikan kemampuan untuk mengatasi masalah dengan cara yang baru, mempunyai kemampuan dalam mengatasi masalah dan mampu melakukan hubungan interpersonal.

Hubungan Interpersonal peplau diakhiri dengan fase resolusi yang merupakan fase dimana klien melepaskan diri dari ketergantunganya dengan perawat dan klien ini mampu mempunyai cara baru dalam mengatasi masalah (Peplau1952 dalam Parker \& Smith, 2010) isolasi sosial dan risiko perilaku kakarasan adalah masalah yang dirasakan oleh klien, dan pada tahap ini klien mampu mengatasi masalah dengan cara baru yang sudah di pelajarinya. Upaya yang dilakukan perawat dalam fase ini adalah memotivasi klien untuk tetap melakukan cara-cara yang sudah klien miliki dengan tetap mengevaluasi kemampuan klien sehingga diharapkan klien mampu 
menggunakan cara-cara tersebut selamanya.Hal ini perlu adanya dukungan dari keluarga dan masyarakat sekitar.

Hubungan interpersonal Peplau dengan menggunakan pendekatan Stuart sangat sesuai dilakukan pada klien dengan isolasi sosial Klien dengan isolasi sosial cenderung sulit untuk dapat mengungkapkan perasaannya dengan baik kepada orang yang belum dikenal, dengan adanya fasefase dalam hubungan interpersonal Peplau memungkinkan perawat dapat membina hubungan salin percaya dengan klien, setelah terjalin hubungan saling percaya klien dapat mengungkapkan perasaan klien dengan baik sehingga dapat diselesaikan masalah klien dengan baik.. Tahapan-tahapan hubungan ini membuat klien percaya dengan kehadiran perawat sehingga perawat dapat denan mudah melakukan asuhan keperawatan sesuai dengan yang dibutuhkan oleh klien.

\section{SIMPULAN DAN SARAN \\ Simpulan}

Ada penurunan tanda dan gejala secara kognitif afektif, fisiologis, perilaku, sosial dan peningkatan kemampuan klien dan keluarga.

\section{Saran}

Klien dengan isolasi sosial diharapkan dapat diberikan terapi Social skill training.

\section{DAFTAR PUSTAKA}

Marilyn, E, P \& Mariaine, C, S (2010) Nursing Theories \& Nursing Practice. Davis Company, philadelphia
Rufollo, et all (2005) Support Empowerment And Education Study Of Multiple Family Group Psycoeducation. Jurnal

Stuart, G. W. (2013). Principles and Practice of Psychiatric Nursing (9 ed.). Missouri: Mosby, Inc.

Syukri, M., Keliat, B.A, Mustikasari (2014). Manajemen asuhan keperawatan diagnosis halusinasi dan isolasi sosial yang mendapat CBSST dan terapi psikoedukasi keluarga menggunakan pendekatan Stuart dan model hubungan interpersonal Peplau di ruang Yudistira RSMM Bogor. (KIA). Depok.FIK-UI. Tidak dipublikasikan

Townsend, M.C. (2009). Psychiatric Mental Health Nursing Concepts of Care in Evidence-Based Practice.Sixth Edition. Philadelphia. F.A Davis Company

Wahyuningsih, D\& Keliat B.A. \& Hastono SP (2009). Pengaruh Assertiveness Training Terhadap Perilaku Kekerasan pada Klien Skizofrenia. (Tesis).Depok. Tidak dipublikasikan

Wilkison M.J \& Ahern, R.A (2012) Buku Saku Diagnosa Keperawatan, Diagnosa NANDA, Intervensi NIC, Kriteria Hasil NOC ed 9 alih bahasa Esti Wahyuningsih, EGC Jakarta. 